\title{
Crime and Punishment, Rehabilitation or Revenge: Bioethics for Prisoners?
}

\author{
Leigh E. Rich • Michael A. Ashby
}

Published online: 26 July 2014

(C) Journal of Bioethical Inquiry Pty Ltd 2014

With some exceptions, it appears that the nonincarcerated world spends little time, if any at all, thinking about how prisoners are treated, whether during detainment or incarceration, after release, or when being put to state-sanctioned death. Of course, in part this is understandable, as the processes of punishment for breaking the social contract have moved from being public spectacle (once serving as a display of the sovereign's power and as simultaneous warning and entertainment for lookers-on) to a private and "strange scientifico-juridical complex" (Foucault 1995, 19) with the veneer of "modernity" and "civility," theoretically drawing a clear line between the horrors of the crimes committed and those of the punishment (Sarat 2014). But even in the 21 st century, the distinction is fuzzy at best. Incarcerated populations around the globe continue to be at greater risk of infectious diseases than nonincarcerated persons in the same communities (see da Cruz and Rich 2014), prisoners are exposed to drug use,

L. E. Rich $(\bowtie)$

Department of Health Sciences (Public Health), Armstrong

State University, 11935 Abercorn Street, University Hall

154F, Savannah, GA 31419, USA

e-mail: leigh.rich@armstrong.edu

M. A. Ashby

Palliative Care Service, Royal Hobart Hospital, Southern Tasmania Area Health Service, and School of Medicine, Faculty of Health Sciences, University of Tasmania, 1st Floor, Peacock Building, Repatriation Centre, 90 Davey Street, Hobart, TAS 7000, Australia

e-mail: michael.ashby@dhhs.tas.gov.au violence, and rape in settings referred to as "controlled" environments in the name of "public safety" (Rich and da Cruz 2014), and parolees may be stripped of certain civil rights and left stigmatized and in states similar to or worse than those prior to incarceration (Alexander 2010) - all while data exist indicating that socioeconomic hardships and structural violence make some individuals more likely to be arrested and imprisoned than others.

Moreover, when the plight of prisoners is broached in public discussions, it often is dismissed or disparaged. For example, on Friday, June 20, 2014, the U.S. television program CBS This Morning featured a story about Jeremy Meeks, a man from California who garnered (inter)national attention after his "mug shot for an arrest on felony weapons charges went viral on social media due to his widely admired looks" (Crimesider Staff 2014, para. 1). His photo that was "posted online by the Stockton Police Department ... attract[ed] more than 95,000 'likes"' in less than a week's time, with people "praising his high cheek bones, chiseled face and striking blue eyes" (Crimesider Staff 2014, para. 3). Individuals also created and posted mockups ("memes," in Internet parlance) featuring Meeks' image as a fashion model, among others, and news anchors, media commentators, and comedians, as they are wont to do, weighed in during the days and the media storm that followed. Meeks' wife and other family members and friends responded, angry at this form of attention, and emphasized that "people are taking it as a joke, thinking it's funny talking about his looks, saying all kinds of crazy things" (family friend cited in Crimesider Staff 2014, 
para. 2). And they are right to feel this way. Although $C B S$ This Morning was not the first to report the story nor is the a.m. show necessarily a bastion of "hard" news, even the three anchors who headline the program (and report vignettes of news stories in between interviews and other "soft" features) behaved inappropriately, unprofessionally, and inhumanely in their reaction. Cohost Gayle King, in the media personality "banter" following the report, stated that she suspects Meeks will be "very popular" in prison, a sentiment host Charlie Rose and co-host Norah O'Donnell found humorous. ${ }^{1}$ Rose then added an incomprehensible (on many levels) comment using the term "Bubba" that was difficult to decipher underneath the laughing (a search of CBS News and even the Internet resulted in no videos of this clip), and King, potentially realizing her cruel thoughtlessness, backtracked and suggested that Meeks has a "good personality" (read: of course that was what she really meant by being "popular"), although this, too, was said a bit tongue-in-cheek, as if she was worried more about the television network censors and the "family friendliness" of the show than what her utterance insinuated. O'Donnell, though having laughed following King's original comment, began to look uncomfortable and briefly noted that an unseen producer was urging them to move on.

It is appalling, though perhaps sadly not surprising, that these national anchors would make light of rape or other violence in prison, suggesting that the safety and well-being of those incarcerated are nothing but a laughing matter to be enjoyed over morning coffee.

Modern methods of execution also have not been able to guarantee a "humane" death (if such a thing exists, particularly as a form of "justice" at the hands of the state). As Austin Sarat examines in his book Gruesome Spectacles, the bureaucratic penal system "imagine[s] the body as a legible text, readable for what it can tell us about the capacity of technology to move us

\footnotetext{
${ }^{1}$ The CBS News website (2014) lists Charlie Rose, a veteran journalist known for his one-on-one interviews with political figures and celebrities, as the "host" of CBS This Morning, while Norah O'Donnell and Gayle King are listed as "co-hosts." King is also known as the longtime friend of Oprah Winfrey.

${ }^{2}$ Merriam-Webster defines the term "Bubba" as "a stereotypical nickname of Southern white males ... often disparaging: REDNECK" (2014, emphasis original), with other online "sources" (such as UrbanDictionary.com) suggesting racist and homophobic prison-related connotations about inmates with power who are physically forceful and violent. These examples are too malicious to repeat here.
}

from life to death, swiftly and painlessly" (Sarat 2014, 4), in an attempt to distinguish between the criminality of murder and the legality of capital punishment. However, real cases suggest otherwise. In Florida in 1997, for example, after an electrocution apparatus and an inmate caught fire during an execution, the prison medical director concluded that prior to the equipment failure the prisoner had "lurched up in his seat and balled up his fists - the normal reaction to high voltage. ... 'I saw no evidence of pain or suffering by the inmate throughout the entire process. In my professional opinion, he died a very quick, humane death"' (cited in Sarat 2014, 3). Even had the fire not occurred, the director's description of a "normal reaction to high voltage" and a lack of "evidence of pain or suffering" is nonsensical. Moreover, as Sarat notes, "[o]f the approximately nine thousand capital sentences carried out in the United States from 1890 to 2010 , we know of 276 that were botched-79 from 1900 to 1919,70 from 1920 to 1949, 23 from 1950 to 1979 , and 104 from 1980 to 2010 " $(2014,6)$ - to say nothing of the dubious justification and pain or suffering of executions performed according to plan.

While the daily lives of the incarcerated are likely to go unnoticed by the rest of society in the modern prison system, these "errors" do seem to make headlines, as do popular fictional programs such as Prison Break, $O z$, Orange Is the New Black, Bad Girls, Prisoners' Wives, and Wentworth that range from the bleak to the comedic. Both of these forms of attention, however, remain voyeuristic, perhaps not much different than the display of "torture as a technique of pain" once meted out in the public square (Foucault 1995, 15) and no more conducive to changing the practice of penal "science" to ensure equivalence of care for prisoners (as laid out by the United Nations' Principles of Medical Ethics) and protections against "cruel and unusual punishment" (as, for example, stated in the Eighth Amendment of the U.S. Constitution).

Thus, we are still left with unanswered questions: Who are inmates and what are their lives (before, during, and after incarceration) really like? What do they owe the state for their crimes? What does the state-and we as the public - owe them? What is the purpose of incarceration and should the imprisoned be hidden behind "the meticulously sealed wall, uncrossable in either direction" (Foucault 1995, 116), and so forgotten and their needs suspended? Does the current system (steeped in a "penal populism" that emerged in many places in 
the past several decades) serve as effective punishment of past crimes, deterrence of future crimes, or promotion of a better society? Or is the system rife with basic human rights violations that merely further a biased and inhumane approach to disobedience and ensure the perpetuation of a (specific) prisoner class?

Most people, in Western countries anyway, live in this dichotomized world where good people in society are protected, often inadequately as they would see it, by a justice system that keeps offenders locked up away from them. Many don't even know where prisons are located, and more and more people around the world reside in "gated" communities to protect themselves from crime. Those who have never visited a prison say it is too soft. Politicians know that there are no votes in prison reforms (or in prisons and among some parolees, for that matter), and justice must be tough. And everywhere refugees and illegal immigrants are subject to regimes of a criminal nature. This is a very big "other" to build, a potentially dangerous one, too, as history and modern terrorism and crime rates show.

It also is an other we gaze upon through distanced and unfocused spectacles. For example, one of us (MA) lives in the capital of a state of Australia that was founded in 1804 and was soon to become the biggest and most notorious penal colony in the British Empire: Hobart in Van Diemen's Land, now Tasmania. This is a place where the Quakers travelled "out of concern" in early colonial times to minister to the distant penal colony in 1832 (University of Tasmania n.d.). Rights for prisoners, however, are advocated only by a few here today, with notable exceptions such as lawyer Greg Barns (see, for example, http://www.abc.net.au/news/ greg-barns/27578), even while Port Arthur on the Tasman peninsula has become a historic site visited by thousands of tourists every year (just as in the United Kingdom families from around the globe listen alongside school parties to the violent history of the Tower of London, complete with beheaded queens and torture chambers, as a form of holiday entertainment). Visitors to Port Arthur are shown a "model prison" approach to correction used in the 1850s that relied on solitary confinement and religious reorientation, highlighting the transition to more "modern" forms of punishment. This isolation, however, was as much feared as the terrible flogging to which prisoners were subjected for the most menial of offenses.

In April 1996, Port Arthur also came to world attention with the massacre of 35 people by the lone gunman
Martin Bryant, a tragic modern horror sadly all too well known in the United States: the random murder spree by a person motivated by psychiatric mayhem or terrorist inclinations. There were many thoughts about the possible operation of bad karmic forces at the time of the massacre. Yet, real conversations about crime and punishment continue not to be had.

On the other side of the globe, one of us (LR) lives in a country where there are an estimated 2.4 million people incarcerated (Wagner and Sakala 2014; J.F. 2014). This incarcerated population is bigger than the entire citizenry of many smaller jurisdictions - equivalent to the whole population of, say, Slovenia and more than all of Latvia in jail. However, while the U.S. situation is often held up as the most disturbing, the global picture also is very bleak (see Walmsley 2014).

And, yet, what do we really know of prisoners?

Banished to the outer bounds of society and social consciousness, prisoners rarely cross our minds, let alone our paths, and few would think of employing compassion when it comes to criminals. Indeed, some deeds committed are so cruel that it would be unthinkable not to put victims first. But "choosing sides" is not so simple. Dr. Gwen Adshead, a psychotherapist at the U.K.'s Broadmoor top-security forensic detention center, works with some of the most psychiatrically disturbed incarcerated offenders in the world (see Urwin 2012). She says that when she interviews a new prisoner, she always asks why they come to be sitting where they are and tries to look at the child that was once in the adult now before her. Her appeal to humanity, with people who have committed serious and often horrible crimes of violence, is firm but decent. There are clear boundaries but these are therapeutic and aimed at rehabilitation, even for those from the most damaged backgrounds and who enjoy no public sympathy.

If it is accepted that psychodynamics explain and indeed offer a channel for understanding, possible amelioration, or even rehabilitation of people who carry damage, and in turn damage, then so-called correctional services surely would be the most important place to start. Instead, the community often votes for "life means life," abolition of suspended sentences, and a "throw away the key" mentality that reeks of fear and revenge rather than rehabilitation. Despite the term "correctional" services with its therapeutic tone, real improvement is buried in institutional settings that mirror in the psychoanalytic sense the very reverse of what they purport to achieve (see, e.g., Rich and da Cruz 2014). 
This is not to pretend that it is easy to work with people from painful, disadvantaged backgrounds and who often make it hard to recognize the dignity of the human person upon which the whole human rights edifice is constructed.

But that should not mean that we shouldn't ever try. Or attempt to understand how lawbreakers come to be and prevent criminal activity in the first place — which likely means addressing socioeconomic disparities and biases inherent in societies everywhere.

And perhaps we need to not ignore or look upon prisoners as some opposed (or romanticized) other but begin to recognize them as members of society, as part of a continuum of human behavior that enfolds us all.

Those who try to understand and reach out to prisoners, however, are usually unpopular and accused of ignoring the victims. The late British politician and social reformer Lord Frank Longford (1902-2001) horrified the public by corresponding with the Moors murderer Ian Brady and, perhaps with even greater notoriety and incomprehension, with Brady's accomplice, Myra Hindley (Stanford 2003). These interventions on behalf of hundreds of prisoners by Longford were based on a deep Christian (Catholic) belief in the duty to treat everyone with human dignity and always allow the possibility of redemption and rehabilitation, even for the worst of crimes, similar to the Quakers in Tasmania.

Writers who try to tell the stories of offenders also are often given a hard time, as if an attempt at professional analysis (and perhaps comprehension?) is somehow dangerous and disrespectful. In Joe Cinque's Consolation, for example, Australian writer Helen Garner (2004) tried to get inside the head of the young woman at the heart of a story of a murder of a young man by his then-girlfriend, but Garner was not given direct access to her and so ended up being seen (ironically) as too sympathetic to the victim, although she set out to try and explain something inexplicable. On the other side, when Gitta Sereny in Cries Unheard: Why Children Kill: The Story of Mary Bell (1998) investigated the life and motives of a member of the small tragic population of children who murder other children, her book "caused a furor when it was published in Britain in 1998" and she was "[a]cclaimed by some reviewers and criticized by others" (Fox 2012, para. 4-5). (She also wrote of her cat-and-mouse relationship with Hitler's last living minister in Albert Speer: His Battle With Truth [1995], so her relationship to evil and its proximities is clear.) And philosopher Hannah Arendt was ostracized and sent death threats after the publication of her observations and examination of the trial of Adolph Eichmann in Israel. Such endeavors, and the writers and scholars who undertake a deeper look at crime and the incarcerated, usually excite public anger as they question the orthodoxy of "hang 'em high."

This is not to suggest that victims of crime do not need to be cared for, justice attended, or the public kept as safe as possible. But current methods-like those in Tasmania in the 1850 s or elsewhere centuries beforeseem to fail on several levels. By locking people away for more minor, non-violent offenses, for example, society is only made more dangerous by consigning to an unsafe and damaging environment those who are already often struggling (see, e.g., Dyer 2000). Drug use and psychiatric disorders dominate prisons: Up to 70 percent of prisoners in the United Kingdom are said to have some form of mental illness (see Mental Health Foundation n.d.). In many urban city centers, the criminal justice, health, and education systems all converge, sharing clientele. And different penalties are often applied to different populations, inequalities in society that get reified (knowingly or not) within the law. Violence should be the only grounds for automatic incarceration. What is presently happening doesn't work.

In a memorable concert inside one of the most infamous U.S. jails, Johnny Cash sang what most prisoners likely feel about any institution:

San Quentin, I hate every inch of you.

You've cut me and have scarred me thru an' thru....

San Quentin, may you rot and burn in hell.

May your walls fall and may I live to tell.

May all the world forget you ever stood.

And may all the world regret you did no good

(Cash 2000-2014, para. 2 and para. 4).

All hope, however, may not be lost. At Sing Sing, surely another notorious prison, innovative projects are under way to improve things (Drumming 2014; see also San Quentin's Prison University Project at http://www. prisonuniversityproject.org/home).

It is to be hoped that by bringing the ethics of the treatment of prisoners into sharp focus, as this issue of the Journal of Bioethical Inquiry offers, it can be seen that it is, firstly, right and, secondly, good sense in terms of community self-interest to ensure that prisons do not continue to recapitulate the wrongs they seek to rectify or perpetuate the cruel, degrading, and pointless penal 
practices that further the crimes they are supposed to deter.

Central to all of these concerns is the need for the United Nations' (1982) “equal treatment" principle to be firmly established and operationalized everywhere, so that prisoners are afforded the same rights with regard to health maintenance, prevention of disease, and treatment of illness and injuries as those who are free. Treatment consent and treatment abatement procedures and standards also should apply.

Some progress has been made on these fronts, but certainly not enough. This was made clear in the comments by the CBS This Morning anchors (and, of course, nearly every police procedural one watches on television): When else would upstanding citizens make light of rape (or illness or ill treatment or death) as one's "just desserts"? More work needs to be done - not in spite of justice and victims' rights but because an "eye for an eye" was never a good moral solution and we need to intervene in the cycle of poverty and prejudice that tends to create prisoners in the first place.

Equivalence isn't easy: Real crime cannot go unpunished; it is hard to garner support and earmark resources for incarcerated populations when many members of the non-incarcerated also are suffering; and issues of public safety come into play with prisoners in ways absent among the public. But these cannot be reasons to disregard principles of autonomy, beneficence, nonmaleficence, and justice or continue to relegate inmates to the forgotten and far away. No matter how strong the desire for punishment for even violent crimes, it is appalling to read of cruel and unjust treatment of prisoners, such as the 167 days of forced feedings endured by the perpetrators of the IRA bombing campaign in London in 1973 or the waterboarding and other "interrogation techniques" used by all in the "coalition of the willing" at Abu Ghraib.

As Marian Price, who went on a hunger strike after she was jailed for her part in the London bombings, described:

Four male prison officers tie you into the chair so tightly with sheets you can't struggle. You clench your teeth to try to keep your mouth closed but they push a metal spring device around your jaw to prise it open. They force a wooden clamp with a hole in the middle into your mouth. Then, they insert a big rubber tube down that. They hold your head back. You can't move. They throw whatever they like into the food mixer - orange juice, soup, or cartons of cream if they want to beef up the calories. They take jugs of this gruel from the food mixer and pour it into a funnel attached to the tube. The force-feeding takes fifteen minutes but it feels like forever. You're in control of nothing. You're terrified the food will go down the wrong way and you won't be able to let them know because you can't speak or move. You're frightened you'll choke to death (cited in Mansfield 2010, 148-149).

The loss (or removal) of a fundamental sovereignty over one's body, intrinsically linked to one's liberty, should never be taken lightly; rather, the highest standards of due process should apply. This is true for both the non-incarcerated and the incarcerated and extends to issues such as treatment refusal or removal, even when leading to death (e.g., from a hunger strike or by declining medical treatment for a fatal condition). For the imprisoned individual, however, the body (and being) is "held in custody" at the determination of the state (or the crown), enabling the powers-that-be to "violate" the person and even "protect" the person from suicide in the name of state interests and/or public policy considerations. These are rooted in the sovereign's power to exact punishment against and safeguard others from those who have committed offense (in most places today with the requirement for due process, though this has not always been the case) as well as a Western religious and common law idea that suicide "was seen as a form of felonious homicide that offended both against God and the King's interest in the life of his citizens" (Rodriguez v. British Columbia (Attorney General), [1993] 3 S.C.R. 519, at I(b)(i) "History of the Suicide Provisions"). Because prisoners and detainees have lost certain basic rights over body and the self, this means that even greater ethical considerations and obligations should apply.

Prisoners' rights must be respected lest we lose any moral legitimacy we may have originally had.

As Michel Foucault explains in Discipline and Pun$i s h$, while in our modern times we have shifted in a more humane direction - moving away from intentionally punishing the body as retribution for breaking the law to instead controlling the body as a means for disciplining and reforming the mind and the soul- this transformation has physically and politically removed prisoners as members from society, making them vulnerable in a different way by rendering them invisible and devalued. 
The prison body has thus faded from view, as a whole and individually, making it difficult to recognize how the penal system continues to impose corporal harms. Foucault emphasizes: "[A] punishment like forced labour or even imprisonment - mere loss of liberty - has never functioned without a certain additional element of punishment that certainly concerns the body itself: rationing of food, sexual deprivation, corporal punishment, solitary confinement" and, as current research shows, overcrowding, violence, and disease: "There remains, therefore, a trace of 'torture' in the modern mechanisms of criminal justice - a trace that has not been entirely overcome, but which is enveloped, increasingly, by the non-corporal nature of the penal system" (Foucault 1995, 15-16).

\section{References}

Alexander, M. 2010. The new Jim Crow: Mass incarceration in the age of colorblindness. New York: The New Press.

Cash, J.R. 2000-2014. San Quentin. AZLyrics.com. http://www. azlyrics.com/lyrics/johnnycash/sanquentin.html.

CBS News. 2014. Correspondents \& anchors. http://www. cbspressexpress.com/cbs-news/correspondents-and-anchors.

Crimesider Staff. 2014. Report: Wife of Jeremy Meeks furious about viral mug shot. CBSnews.com, June 23. http://www. cbsnews.com/news/report-wife-of-jeremy-meeks-furiousabout-viral-mug-shot/.

da Cruz, J., and L.E. Rich. 2014. Competing imperatives? Moral and public health duties of preventing and treating infectious disease in prisons. Journal of Bioethical Inquiry 11(1): 105-108.

Drumming, N. 2014. Prisoners try to prosper in "The University of Sing-Sing.” Salon, March 21. http://www.salon.com/2014/03/ 31/prisoners try_to prosper_in the university_of sing_sing/.

Dyer, J. 2000. The perpetual prisoner machine: How America profits from crime. Boulder: Westview Press.

Fox, M. 2012. Gitta Sereny, author who focused on evildoers, dies at 91. The New York Times, June 23. http://www.nytimes. com/2012/06/24/books/gitta-sereny-who-wrote-about-evildies-at-91.html? $\mathrm{r}=0$.

Foucault, F. 1995. Discipline and punish: The birth of the prison, 2nd ed. Translated by A. Sheridan. New York: Vintage Books.
Garner, H. 2004. Joe Cinque's consolation: A true story of death, grief and the law. Sydney: Picador.

J.F. 2014. America's prison population: Who, what, where and why. The Economist, March 13. http://www.economist.com/ blogs/democracyinamerica/2014/03/americas-prisonpopulation.

Mansfield, M. 2010. Memoirs of a radical lawyer. London: Bloomsbury Publishing.

Mental Health Foundation. No date. Mental health statistics: Prisons http://www.mentalhealth.org.uk/help-information/ mental-health-statistics/prisons/.

Merriam-Webster. 2014. Bubba. http://www.merriam-webster. com/dictionary/bubba.

Rich, L.E., and J. da Cruz. 2014. HIV/AIDS among Brazil's prison populations: Significant political, public health, and human rights implications for failing to provide prisoners with adequate care. Journal of Infectious Diseases and Therapy 2(3): 1000143. http://dx.doi.org/10.4172/2332-0877.1000143.

Sarat, A. 2014. Gruesome spectacles: Botched executions and America's death penalty. Stanford: Stanford University Press.

Sereny, G. 1995. Albert Speer: His battle with truth. London: Macmillan.

Sereny, G. 1998. Cries unheard: Why children kill: The story of Mary Bell. London: Macmillan.

Stanford, P. 2003. The outcast's outcast: A biography of Lord Longford. Stroud: Sutton Publishing Ltd.

United Nations. 1982. Principles of medical ethics relevant to the role of health personnel, particularly physicians, in the protection of prisoners and detainees against torture and other cruel, inhuman or degrading treatment or punishment. http:// www.un.org/documents/ga/res/37/a37r194.htm.

University of Tasmania. No date. Quaker life in Tasmania: The conscience of the colony. http://www.utas.edu.au/library/ exhibitions/quaker/conscience_colony/conscience_colony. html.

Urwin, R. 2012. There's evil in all of us, says Broadmoor doctor Gwen Adshead. London Evening Standard, July 2. http:// www.standard.co.uk/lifestyle/london-life/theres-evil-in-allof-us-says-broadmoor-doctor-gwen-adshead-7903529.html.

Wagner, P., and L. Sakala. 2014. Mass incarceration: The whole pie: A Prison Policy Initiative briefing. Prison Policy Initiative, March 12. http://www.prisonpolicy.org/reports/ pie.html.

Walmsley, R. 2014. World pre-trial/remand imprisonment list, 2nd ed. International Centre for Prison Studies. http://www. prisonstudies.org/sites/prisonstudies.org/files/resources/ downloads/world_pre-trial_imprisonment_list_2nd_edition 1.pdf. 